\title{
Laporan Pertama di Sulawesi Selatan: Karakter Morfologi dan Molekuler Nematoda Puru Akar yang Berasosiasi dengan Akar Padi di Kabupaten Wajo, Sulawesi Selatan
}

\author{
First Report in South Sulawesi: Morphological and Molecular Characters of \\ Root Knot Nematodes Associated with Rice Root \\ in Wajo, South Sulawesi
}

\author{
Hishar Mirsam ${ }^{1) *}$ \& Fitrianingrum Kurniawati²) \\ 1) Program Studi Agroteknologi, Fakultas Pertanian, Universitas Cokroaminoto Palopo \\ Jln. Lamaranginang Kampus II UNCP, Palopo, Sulawesi Selatan 91911 \\ 2)Departemen Proteksi Tanaman, Fakultas Pertanian, Institut Pertanian Bogor \\ Jln. Meranti, Kampus IPB Dramaga, Bogor, Jawa Barat 16680 \\ *Penulis untuk korespondensi.E-mail: hisharmirsam@yahoo.co.id
}

Diterima 6 Februari 2018; diterima untuk diterbitkan 6 Juni 2018

\begin{abstract}
Root Knot Nematode (RKN) is one of the most important cosmopolite parasitic nematode species. Reports on RKN associated with rice root in Indonesia are still limited in West Java and Yogyakarta. This study aimed to identify the RKN associated with rice root in Sub-district of Bola, District of Wajo, South Sulawesi, based on morphological and molecular characters. Sampling was carried out by purposive method based on specific criteria of sample, i.e. root knot.Identification of root knot nematode (RKN) infestation in field was done by observing the primary and secondary symptoms. Morphological identification was carried out based on characters of juvenile 2 and the female perineal pattern. Molecular identification was based on amplification of $r$-DNA by polymerase chain reaction technique using primers $r D N A 2$ and $r D N A$ 1.58s. RKN were detected associated with the incidence of root knot in rice plant. RKN was identified as Meloidogyne graminicola based on morphological characters of juvenile 2 and the female perineal pattern. PCR using primer rDNA 2/rDNA 1.58s successfully amplified a DNA band of RKN of $\pm 500 \mathrm{bp}$. Nucleotide sequence analysis showed that RKN isolated from Wajo was closely related to M. graminicola isolated from Nepal, China, India, Madagascar, and USA with homology of 98.1-100.00\%.
\end{abstract}

Keywords: juvenile 2, Meloidogyne graminicola, nucleotide, perineal pattern

\section{INTISARI}

Nematoda puru akar (NPA) merupakan salah satu jenis nematoda parasit penting yang bersifat kosmopolit. Laporan NPA yang berasosiasi dengan akar tanaman padi di Indonesia masih terbatas di Jawa Barat dan Yogyakarta. Penelitian ini bertujuan mengidentifikasi NPA yang berasosiasi dengan akar tanaman padi di Kabupaten Wajo, Sulawesi Selatan berdasarkan karakter morfologi dan molekuler. Pengambilan sampel dilakukan secara purposif dengan memilih sampel berdasarkan pada kriteria gejala spesifik penyakit puru akar. Identifikasi serangan dilakukan dengan mengamati gejala primer dan gejala sekunder. Identifikasi morfologi dilakukan dengan pengamatan karakter morfologi juvenil 2 dan pola perineal NPA betina.Identifikasi molekuler dilakukan dengan teknik polymerase chain reaction (PCR) untuk mengamplifikasi wilayah internal transcribed spacer (ITS) ribosomal DNA (rDNA) menggunakan pasangan primer rDNA2 dan rDNA1.58s. NPA ditemukan berasosiasi dengan akar tanaman padi yang memperlihatkan gejala puru akar. NPA diidentifikasi sebagai Meloidogyne graminicola berdasarkan karakter morfologi juvenil 2 dan pola perineal NPA betina. PCR menggunakan primer rDNA2/rDNA1.58s berhasil mengamplifikasi pita DNA NPA dengan ukuran sekitar 500 bp. Analisis runutan nukleotida menunjukkan isolat NPA asal Wajo-Indonesia memiliki tingkat kekerabatan yang sangat dekat dengan isolat M. graminicola asal Nepal, Cina, India, Madagaskar, dan Amerika Serikat dengan nilai homologi berkisar 98,1-100,0\%.

Kata kunci: juvenil 2, Meloidogyne graminicola, nukleotida, pola perineal 


\section{PENDAHULUAN}

Nematoda puru akar (NPA) merupakan salah satu jenis nematoda parasit penting yang bersifat kosmopolit atau memiliki tanaman inang yang luas. Salah satu tanaman inang yang dapat diserang oleh namatoda ini adalah tanaman padi. Pada tanaman padi, nematoda ini dapat menyebabkan gejala primer berupa puru akar. Gejala khas tanaman padi yang terinfeksi oleh nematoda puru akar ialah terbentuknya puru yang terletak di bagian ujung akar padi yang bengkak dengan membentuk seperti pengait (hook).

NPA yang berasasoasi dengan akar tanaman padi di Indonesia, yaitu spesies Meloidogyne graminicola telah dilaporkan di Pulau Jawa antara lain di Yogyakarta, Bogor, Cirebon, dan Sukabumi (Mulyadi, 1994; Febriyani, 2003; Nujayadi et al., 2015). Di Sulawesi Selatan, keberadaan nematoda ini dianggap tidak penting oleh beberapa petugas yang bekerja di bidang pertanian sehingga serangan NPA ini kurang disadari. Kehilangan hasil akibat infeksi NPA ini telah banyak dilaporkan pada pertanaman padi di seluruh dunia. Di beberapa kawasan Asia Selatan dan Tenggara nematoda ini dilaporkan menyebabkan kerugian antara 20-80\% (Erlan et al., 1993; Padgham et al., 2004; Pokharel et al., 2007; Jaiswal et al., 2011).

Kabupaten Wajo adalah salah satu daerah penghasil beras di Sulawesi Selatan. BPS Kabupaten Wajo (2017) melaporkan peningkatan produksi padi pada tahun 2014, 2015, dan 2016, berturut-turut sebesar 731.387 ton, 756.387 ton, dan 788.953 ton. Peningkatan produksi padi tersebut tidak menggambarkan kondisi pertanaman padi pada seluruh daerah di Kabupaten Wajo. Penyakit puru akar ditemukan menyerang tanaman padi di Kecamatan Bola, Kabupaten Wajo dan diduga disebabkan oleh NPA. Berdasarkan pengamatan langsung di lapangan, serangan NPA di Kabupaten Wajo masih tergolong rendah atau di bawah ambang luka ekonomi. Namun demikian, kondisi ini dapat menjadi buruk jika tidak dilakukan pengendalian sejak dini. Oleh karena itu, perlu dilakukan observasi dan identifikasi lebih lanjut tetang keberadaan NPA yang berasosiasi dengan akar tanaman padi di Kabupaten Wajo, Sulawesi Selatan sebagai upaya pencegahan dan pengendalian NPA tersebut.

Penelitian ini bertujuan mengidentifikasi NPA pada tanaman padi asal Kabupaten Wajo, Sulawesi Selatan berdasarkan karakter morfologi juvenil 2, pola perineal, dan molekuler, serta mengetahui tingkat kekerabatan NPA asal Wajo dengan isolat pada GenBank melalui analisis filogenetika.

\section{BAHAN DAN METODE}

\section{Pengambilan Sampel}

Pengambilan sampel dilakukan pada pertanaman padi di Desa Lempong, Kecamatan Bola, Kabupaten Wajo, Sulawesi Selatan. Pengambilan sampel dilakukan secara purposif dengan memilih sampel berdasarkan pada kriteria gejala spesifik penyakit puru akar. Sampel yang diambil berupa akar padi yang bergejala puru akar. Sampel disimpan dalam kantong plastik secara terpisah dan dibungkus dengan pelepah pisang agar kelembapannya terjaga sehingga nematoda dapat bertahan hidup, kemudian disimpan dalam kotak pendingin (cooling box).

\section{Pengamatan Gejala Serangan NPA}

Kegiatan identifikasi gejala penyakit pada pertanaman padi dilakukan terhadap tanaman bergejala pada bagian tajuk (di atas permukaan tanah) dan terhadap perakaran tanaman. Gejala pada bagian tajuk yang diamati berupa tinggi tanaman (kerdil), warna daun (menguning, klorosis), kelayuan pada siang hari, dan pertumbuhan tanaman padi yang tidak merata, sedangkan gejala pada bagian perakaran berupa bentuk, dan keberadaan puru yang berbentuk pengait (hook).

\section{Ekstraksi Nematoda dengan Teknik Pengabutan}

Ekstraksi nematoda dilakukan dengan metode pengabutan yang merujuk pada metode Hooper et al. (2005). Akar tanaman padi yang bergejala puru akar dibersihkan dengan air mengalir, kemudian dipotongpotong sekitar $\pm 1 \mathrm{~cm}$. Potongan akar padi tersebut diletakkan di atas saringan kasar yang terletak di atas corong. Gelas plastik diletakkan di bagian bawah corong untuk menampung nematoda hasil ekstraksi. Proses ini dilakukan di dalam ruang pengabutan, air melalui nozzle dialirkan ke potongan akar padi. Proses pengabutan dibiarkan selama 48 jam. Setelah itu, gelas plastik yang berisi air disaring dengan menggunakan penyaring 500 mesh untuk memperoleh nematoda. Nematoda yang akan diperoleh adalah juvenil instar ke-2. Hasil ekstraksi nematoda ini didibuat preparat untuk pengamatan morfologi.

\section{Inkubasi Nematoda}

Inkubasi nematoda dilakukan berdasarkan metode Mirsam et al. (2015) yaitu nematoda dibilas menggunakan air steril pada saringan 500 mesh dan di- 
masukkan ke dalam botol gelas. Nematoda diinkubasi selama 48 jam pada suhu ruangan dan diberi udara menggunakan aerator. Inkubasi dilakukan agar sistem pencernaan tubuh nematoda bebas dari sisa-sisa makanan untuk memudahkan pengamatan ciri morfologi dan pengukuran bagian tubuh nematoda.

\section{Pembuatan Preparat Nematoda}

Preparat semipermanen. Preparat semipermanen dibuat mengikuti metode Goodey (1973) yang telah dimodifikasi yaitu tanpa menggunakan glass woll. Lingkaran parafin dibuat di atas gelas obyek menggunakan bor gabus dengan ketebalan yang sama, kemudian diteteskan laktofenol pada bagian tengah lingkaran parafin. Sebanyak 3-5 ekor nematoda juvenil 2 diletakkan pada larutan laktofenol dengan posisi yang sama sejajar, selanjutnya ditutup dengan gelas penutup. Preparat kemudian dipanasi sampai cincin parafin meleleh kembali dan kaca penutup merekat bersama.

Preparat pola perineal. Pembuatan preparat pola perineal dilakukan berdasarkan metode Mirsam et al. (2015), yaitu akar dengan gejala puru dicuci untuk membersihkan tanah yang menempel. Puru dipisahkan dari akar, kemudian direndam selama kurang lebih $24 \mathrm{jam}$. Setelah puru melunak, nematoda betina dicongkel perlahan dari puru dan dipindahkan ke dalam cawan sirakus yang telah berisi asam cuka. Asam cuka berguna untuk menghilangkan lemak yang berada dalam tubuh nematoda betina. Setelah itu, nematoda betina dipindahkan ke gelas objek. Bagian anterior dipotong dengan pisau khusus, kemudian bagian posterior ditekan agar sisa kotoran dan lemak dalam tubuh nematoda keluar. Potongan direndam dalam laktofenol $0,03 \%$ dan dibiarkan sebentar. Bagian posterior disayat dan jaringan di dalam dibuang secara hati-hati, kemudian dipindahkan ke gelas objek lain dengan ditetesi laktofenol dan ditutup dengan gelas penutup. Preparat diamati menggunakan mikroskop kompon. Identifikasi dilakukan mengikuti panduan Eisenback et al. (1981) serta Shurtleff dan Averre (2005).

\section{Pengamatan Morfologi Juvenil 2}

Pengamatan dan identifikasi morfologi juvenil 2 dilakukan dengan melihat ciri dari fase juvenil 2 nematoda tersebut. Pengamatan dilakukan dengan menggunakan mikroskop dan mendokumentasikan dengan menggunakan kamera. Identifikasi dilakukan dengan mengacu pada buku identifikasi nematoda
Plant Parasitic Nematodes: A Pictorial Key to Genera (Mai \& Lyon, 1996) dan dengan mencocokkan beberapa gambar-gambar pada beberapa literatur.

\section{Identifikasi Karakter Molekuler}

Ekstraksi DNA nematoda. Ekstraksi DNA nematoda dari sampel puru mengikuti metode Zouhar et al. (2000). Sebanyak 0,5 g puru akar ditambahkan dengan nitrogen cair, digerus dengan mortar dan pestle. Kemudian ditambahkan bufer ekstrak (50 mM Tris- $\mathrm{HCl} \mathrm{pH}$ 8, $0 ; 0,7 \mathrm{NaCl} ; 10$ mM EDTA; $1 \%$ CTAB; dan 1\% ß-merkaptoetanol) $500 \mu$ l hingga menjadi homogen dengan pistil. Hasil gerusan dimasukkan ke dalam tabung mikro $2 \mathrm{ml}$, kemudian diinkubasi dalam penangas air (water bath) pada suhu $60^{\circ} \mathrm{C}$ selama 2 jam (setiap 10 menit tabung mikro dibolak-balik untuk membantu proses lisis). Tabung mikro dari penangas selanjutnya didinginkan sekitar 3-5 menit pada suhu ruang. Sebanyak $500 \mu \mathrm{l}$ larutan kloroform:isoamilakohol (24:1) ditambahkan dan dicampurkan hingga homogen dengan divorteks selama 5 menit. Suspensi yang terbentuk disentrifugasi selama 20 menit pada kecepatan $11.000 \mathrm{rpm}$. Supernatan hasil sentrifugasi diambil dan dipindahkan ke dalam tabung mikro yang baru. Sodium asetat 3M (pH 5,2) ditambahkan ke dalam supernatan dengan perbandingan 1:10 dan dicampur hingga homogen. Isopropanol sebanyak $2 / 3$ volume supernatan ditambahkan ke dalam tabung dan dicampur hingga homogen. Tabung diinkubasi pada suhu $-20^{\circ} \mathrm{C}$ selama semalam. Suspensi kemudian disentrifugasi pada kecepatan $12.000 \mathrm{rpm}$ selama 15 menit. Cairan dalam tabung dibuang dan pelet (endapan DNA) yang terbentuk dicuci dengan etanol $80 \%$ sebanyak $500 \mathrm{ml}$, kemudian disentrifugasi pada kecepatan 12.000 rpm selama 15 menit. Cairan alkohol yang digunakan untuk mencuci pelet dibuang dan endapan DNA dikeringkan. Bufer Tris EDTA ditambahkan pada tabung mikro sebanyak 30-100 $\mu 1$ sesuai dengan ketebalan endapan DNA.

Amplifikasi DNA. Hasil ekstraksi DNA dilanjutkan dengan melakukan amplifikasi DNA dengan metode PCR. Reaksi PCR dilakukan dengan mencampur go tag green sebanyak 12,5 $\mu 1$, ddH2O 8,5 $\mu 1$, primer rDNA2 $1 \mu \mathrm{l}$, primer rDNA1,58s $1 \mu \mathrm{l}$, dan DNA template $2 \mu$ l. Primer yang digunakan berasal dari Powers et al. (1997) dan Pokharel et al. (2007), yaitu rDNA2 (5'-TTG ATT ACG TCC CTG CCC TTT-3') dan rDNA1,58s (5'-ACG AGC CCG AGT GAT CCA CCG-3'). Siklus PCR terdiri dari tahap inisiasi pada suhu $94^{\circ} \mathrm{C}$ selama 2 menit yang di- 
lanjutkan oleh 25 siklus dari suhu $94^{\circ} \mathrm{C}$ selama 1 menit, $47^{\circ} \mathrm{C}$ selama 1 menit dan $72^{\circ} \mathrm{C}$ selama 1 menit dan ekstensi akhir selama 5 menit pada $72^{\circ} \mathrm{C}$ (Pokharel et al., 2007). DNA nematoda hasil amplifikasi dianalisis dengan elektroforesis. Elektroforesis dilakukan pada tegangan $50 \mathrm{~V}$ selama 60 menit kemudian dilanjutkan pada $100 \mathrm{~V}$ selama 5 menit. Hasil elektroforesis divisualisasi dengan UV transiluminator dan diambil foto dengan kamera.

Analisis runutan nukleotida. Produk amplifikasi dikirim ke $1^{\text {st }}$ Base (Malaysia) untuk disekuen. Hasil sekuen dianalisis menggunakan program basic local alignment search tool (BLAST) dengan program optimasi untuk mendapatkan urutan basa DNA yang terdapat dalam situs National Center for Biotechnology Information (NCBI). Hasil sekuen nukleotida yang diperoleh kemudian dianalisis menggunakan penyejajaran berganda ClustalW pada perangkat lunak Bioedit Sequence Alignment Editor versi 7.1.3. Hubungan kekerabatan antarisolat dikonstruksi menggunakan perangkat lunak Molecular Evolutionary Genetic Analysis Softwareversi 6.06 (MEGA6) dengan bootstrap 1000 kali ulangan.

\section{HASIL DAN PEMBAHASAN}

\section{Gejala NPA di Pertanaman Padi}

Gejala sekunder oleh NPA di pertanaman padi pada umumnya menyebabkan pertumbuhan tanaman tidak merata, tanaman kerdil, daunnya menguning, dan tanaman yang bergejala mudah tercabut (Gambar 1).
Tanaman padi yang teramati tersebut dalam kondisi tidak tergenang oleh air. Gejala tersebut sama dengan gejala yang dijelaskan oleh Bird (1972) bahwa pada umumnya nematoda puru akar menyebabkan gejala sekunder berupa gejala tanaman menjadi kerdil, daunnya pucat, dan layu.

Gejala primer oleh NPA menyebabkan perubahan morfologi akar. Pembentukan puru akar menunjukkan gejala khas tanaman padi terinfeksi oleh NPA. Puru yang terbentuk berada di bagian ujung akar padi yang bengkak dan bengkok dengan membentuk seperti pengait (hook) (Gambar 2). Gejala tersebut menunjukkan gejala yang mirip dengan laporan Mulyadi dan Triman (1995) bahwa NPA menyebabkan terjadinya puru (bengkak) pada akar (ujung akar menjadi membengkak dan membengkok) dan pertumbuhan tanaman terhambat.

\section{Karakter Morfologi NPA Juvenil 2}

Karakter NPA juvenil 2 diidentifikasi sebagai Meloidogyne graminicola. NPA juvenil 2 memiliki khas pada bagian posterior, yaitu ujung ekor terlihat runcing, bergelombang, bulat, serta terdapat bagian hyaline tail terminus. Bagian anterior ditandai dengan set off dan datar. Bagian rongga mulut dilengkapi dengan stilet dengan tipe stomatostylet yang dilengkapi dengan knob. Pada saluran pencernaan terdapat faring yang menghubungkan antara stilet dengan median bulb ke bagian pharyngeal gland lobe. Kelenjar faring ini memiliki posisi tumpang tindih (overlapping) dengan usus (intestine). Karakter

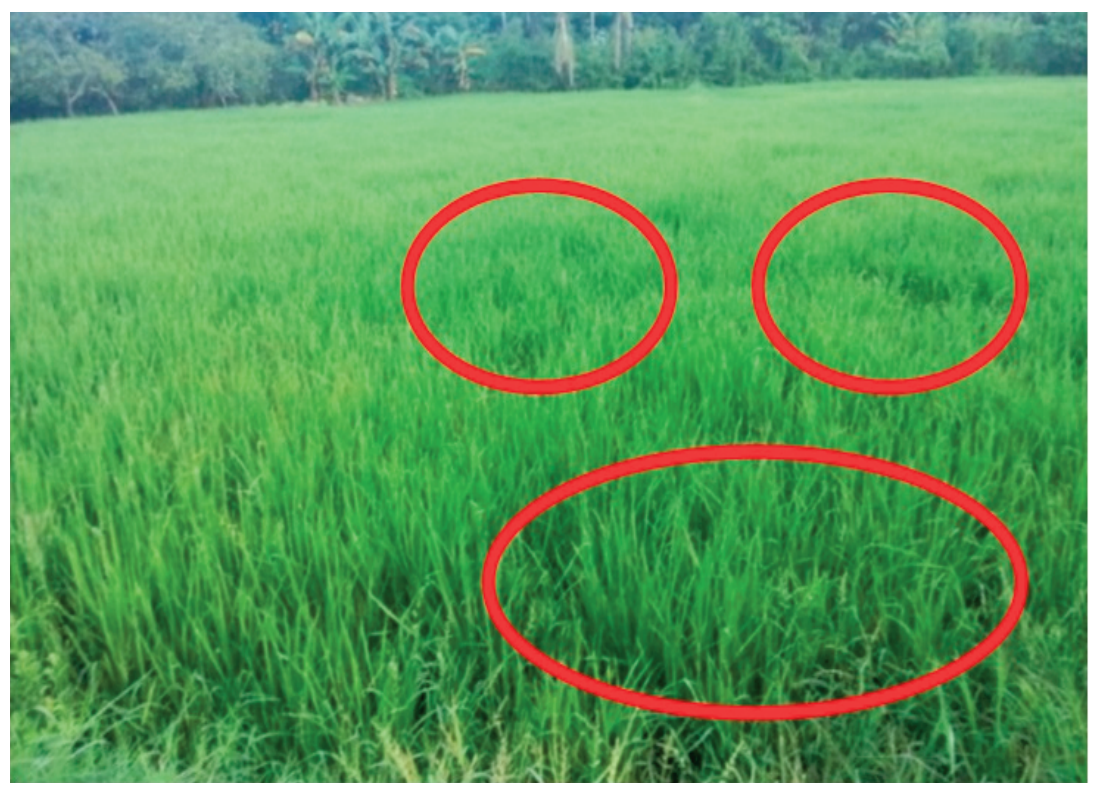

Gambar 1. Gejala pertanaman padi yang terinfeksi nematoda puru akar di Kabupaten Wajo, Sulawesi Selatan; lingkaran merah merupakan gejala spot-spot akibat pertumbuhan tanaman tidak merata 


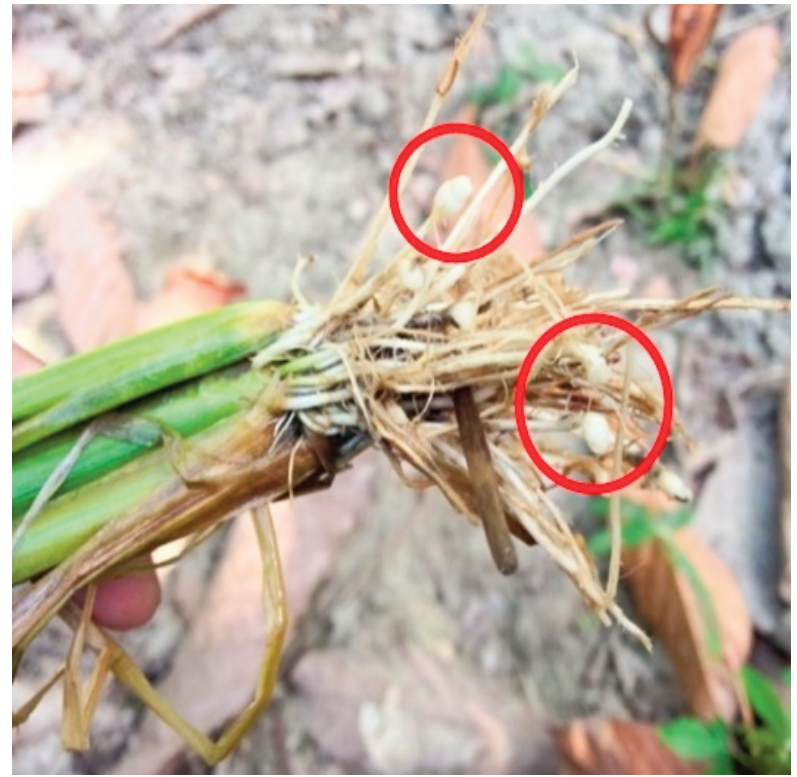

Gambar 2. Gejala puru akar pada akar tanaman padi morfologi yang diperoleh menunjukkan kemiripan dengan karakter yang dilaporkan oleh Golden dan Birchfield (1965), yaitu M. graminicola memiliki ciri bibir yang berbentuk set off dan bagian ekor runcing dengan bagian ujung ekor bulat halus, stilet dilengkapi knob dengan tipe stomato stylet, ujung ekor bergelombang, runcing, dan terdapat bagian hyaline tail terminus, serta kelenjar faring yang overlapping dengan usus (Gambar 3).

\section{Karakter Pola Perineal NPA Betina}

Pola perineal NPA betina yang diidentifikasi terindikasi sebagai spesies $M$. graminicola. Pola perineal sangat khas berupa garis striae yang halus dengan pola berbentuk oval. Garis lengkungan saling terhubung membentuk piramida yang terpusat di bagian tengah (ekor terminus). Pola striae-nya tidak dipisahkan atau tidak memiliki garis lateral. Kemiripan sketsa pola perineal yang diperoleh terlihat jelas dengan sketsa yang dilaporkan oleh Hunt dan Handoo (2009) pada Gambar 4.
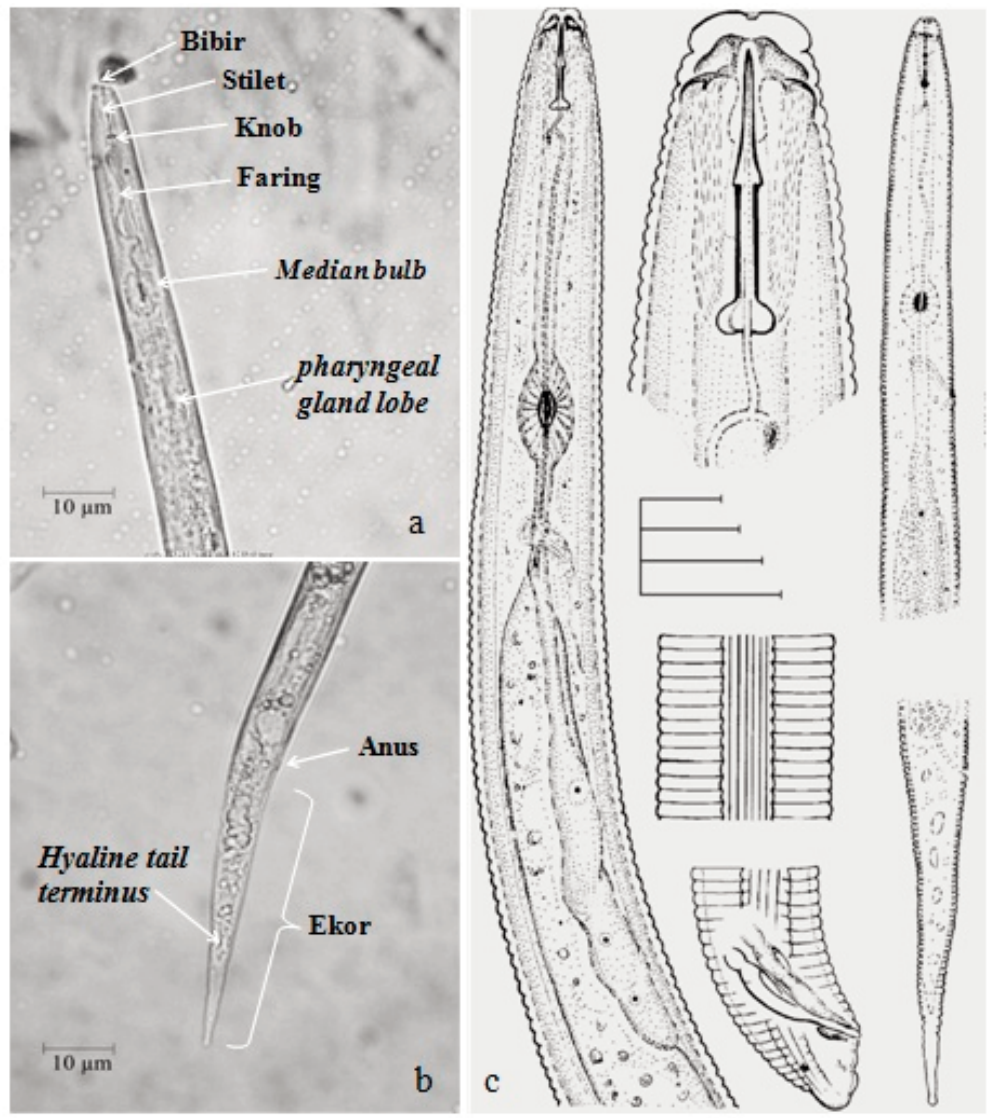

Gambar 3. Morfologi Meloidogyne graminicola juvenil 2 dari akar tanaman padi asal Wajo, Sulawesi Selatan dengan perbesaran mikroskop 1000× [(a) bagian anterior; (b) bagian posterior; (c) karakter morfologi M. graminicola juvenil 2 menurut Golden dan Birchfield (1965)] 


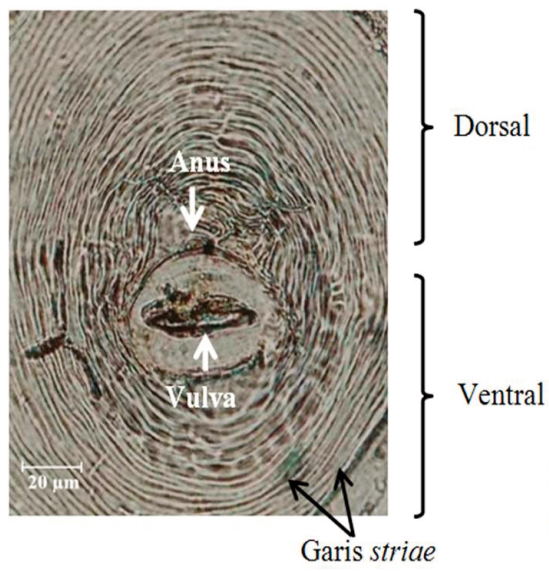

a

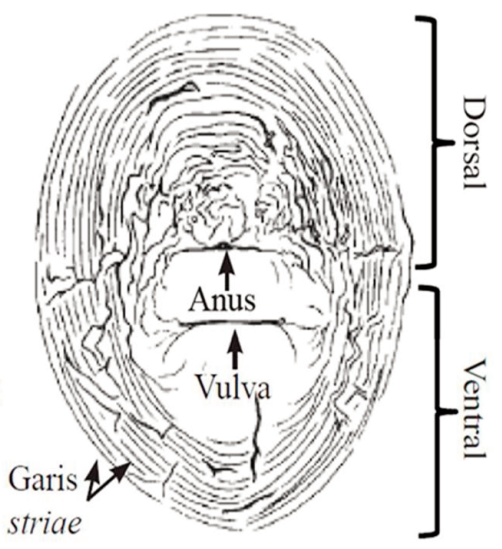

b

Gambar 4. Pola perineal Meloidogyne graminicola [(a) isolat asal Wajo, Sulawesi Selatan dengan perbesaran 400×; (b) sketsa pola perineal M. graminicola menurut Hunt dan Handoo (2009)]

\section{Karakter NPA Berdasarkan Runutan Nukleotida}

Pita DNA NPA yang berasosiasi dengan akar tanaman padi asal Wajo, Sulawesi Selatan berukuran \pm 500 bp berhasil teramplifikasi menggunakan pasangan primer rDNA2 dan rDNA1.58s (Gambar 5). Hal ini memperkuat hasil identifikasi morfologi juvenile 2 dan pola perineal NPA betina yang dilakukan sebelumnya. Esbendshade dan Tirantaphyllou (1990) menjelaskan bahwa pengujian dengan pendekatan biologi molekuler diyakini lebih cepat dan lebih akurat dibandingkan dengan identifikasi karakter morfologi dan pola perineal. Pasangan primer rDNA2/ rDNA1.58s dapat mengenali dan memperbanyak DNA NPA betina dewasa di wilayah internal transcribed spacer (ITS) ribosomal DNA (rDNA). Wilayah ITS terletak pada susunan berulang antara inti $18 \mathrm{~S}$ dan 28S dari gen DNA ribosom dan digunakan sebagai penanda genetik. Menurut Powers et al. (1997), wilayah ITS sangat conserve atau stabil sehingga dapat memberikan penanda genetik yang kuat untuk mengidentifikasi spesies nematoda parasit. Data runutan ITS digunakan untuk membuat pohon filogenetik, mengestimasi struktur populasi genetik, mengevaluasi proses evolusi pada tingkat populasi, dan menentukan identitas taksonomi.

Analisis homologi runutan nukleotida menunjukkkan bahwa NPA isolat Wajo-Indonesia memiliki tingkat homologi tertinggi dengan isolat

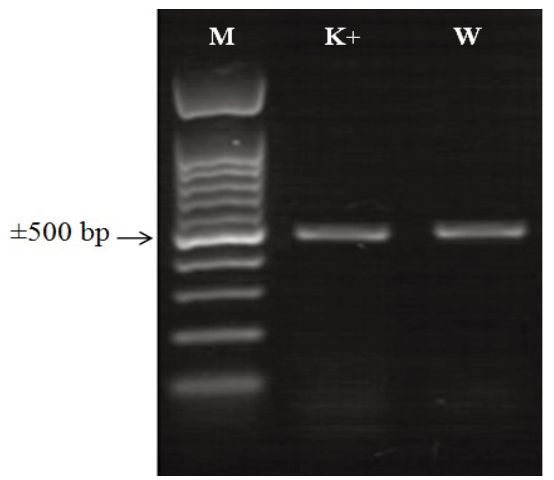

Gambar 5. Hasil amplifikasi DNA NPA yang berasosiasi dengan akar tanaman padi asal Wajo, Sulawesi Selatan pada $1 \%$ gel agarosa; [(M) penanda DNA $100 \mathrm{pb} ;(\mathrm{K}+)$ kontrol positif isolat Bogor; (W) isolat Wajo]

Meloidogyne graminicola asal Nepal, Cina, India, dan Madagaskar, yaitu sebesar $100 \%$. NPA isolat Wajo-Indonesia juga memiliki tingkat homologi yang cukup tinggi dengan isolat $M$. graminicola asal Amerika Serikat sebesar 98,1\% dan homologi sangat rendah dengan isolat pembanding, yaitu isolat Aphelenchoides besseyi asal Costa Rica sebesar $24,7 \%$ (Tabel 1). Hasil amplifikasi DNA NPA isolat Wajo (Indonesia) dikonfirmasi melalui analisis filogenetika. Analisis filogenetika memperlihatkan NPA isolat Wajo berada satu kelompok dengan $M$. graminicola asal Nepal, Cina, India, dan Madagaskar dengan nilai koefisien jarak genetik 0.00 (Gambar 6). 
Tabel 1. Tingkat homologi Meloidogyne graminicola isolat Indonesia Sulawesi Selatan dibandingkan dengan isolat yang berasal dari GenBank

\begin{tabular}{|c|c|c|c|c|c|c|c|c|}
\hline \multirow[t]{2}{*}{ Asal isolat } & \multirow[t]{2}{*}{ Aksesi No. } & \multicolumn{7}{|c|}{ Tingkat homologi (\%) } \\
\hline & & 1 & 2 & 3 & 4 & 5 & 6 & 7 \\
\hline Wajo-Indonesia & $\mathrm{Na}$ & ID & & & & & & \\
\hline Nepal & DQ909044 & 100 & ID & & & & & \\
\hline Cina & KY020414 & 100 & 100 & ID & & & & \\
\hline India & MF320126 & 100 & 100 & 100 & ID & & & \\
\hline Madagaskar & KX372253 & 100 & 100 & 100 & 100 & ID & & \\
\hline Amerika Serikat & EF432571 & 98,1 & 98,1 & 98,1 & 98,1 & 98,1 & ID & \\
\hline Aphelenchoides besseyi Costa Rica & KX356856 & 24,7 & 24,7 & 24,7 & 24,7 & 24,7 & 24,7 & ID \\
\hline
\end{tabular}

Keterangan: $\mathrm{Na}$ (no accession number)

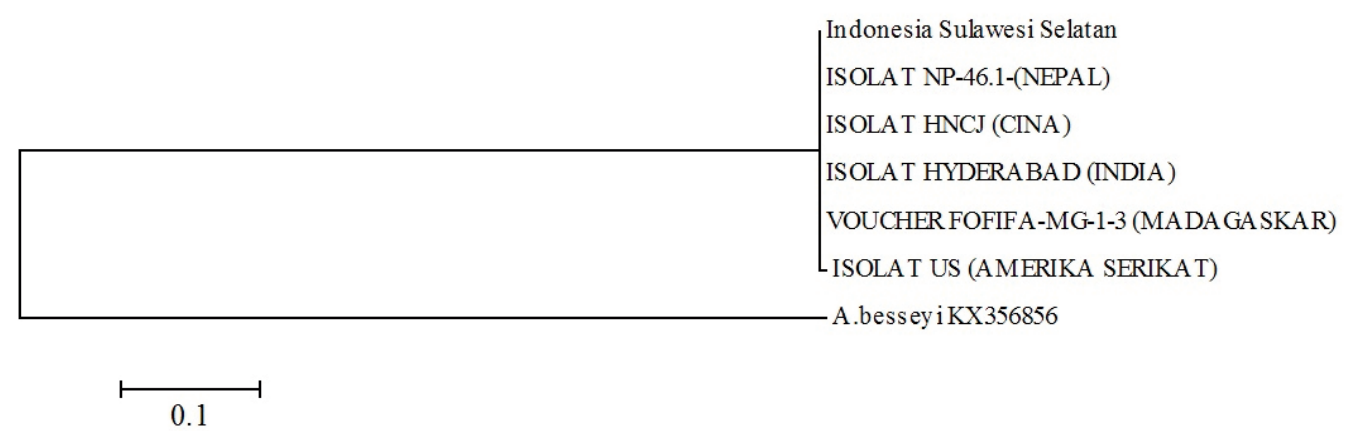

Gambar 6. Pohon filogenetika NPA yang berasosiasi dengan akar tanaman padi asal Wajo, Sulawesi Selatan dengan analisis maximum likelihood tree menggunakan program Bioedit 7.1.3. dan MEGA 6.06; skala di bawah gambar adalah skala nilai koefisien jarak genetik yang menggambarkan jumlah rata-rata perubahan nukleotida di antara isolat

\section{KESIMPULAN}

Nematoda puru akar (NPA) yang berasosiasi dengan akar tanaman padi asal Kabupaten Wajo, Sulawesi Selatan teridentifikasi sebagai spesies Meloidogyne graminicola berdasarkan karakter morfologi juvenil 2, pola perineal NPA betina, dan runutan nukleotida. Analisis runutan nukleotida menunjukkan bahwa NPA asal Wajo-Indonesia memiliki tingkat kekerabatan yang sangat dekat dengan isolat M. garaminicola asal Nepal, Cina, India, Madagaskar, dan Amerika Serikat dengan nilai homologi berkisar antara 98,1-100\%.

Hasil penelitian ini dapat dijadikan data primer untuk menentukan strategi pengendalian $M$. graminicola yang berasosiasi dengan akar padi di Kecamatan Bola, Kabupaten Wajo, Sulawesi Selatan sehingga nematoda parasit ini tidak menyebar lebih luas di wilayah Kabupaten Wajo lainnya.

\section{DAFTAR PUSTAKA}

Bird, A. F. 1972. The Structure of Nematodes. Academic Press, New York, US. 318 p.

Badan Pusat Statistik [BPS] Wajo. 2017. Wajo dalam Angka 2017. BPS Kabupaten Wajo, Makassar, Indonesia. $58 \mathrm{hlm}$.

Eisenback, J.D., H. Hirschmann, J.N. Sasser, \& A.C. Triantaphyllou. 1981. A Guide to the Four Most Common Species of Root-Knot Nematodes (Meloidogyne spp.) with A Pictorial Key. Department of Plant Pathology and Genetic Nort Caroline University and the United States Agency for International Development, North Carolina, US. 48 p.

Erlan, Supratoyo, Mulyadi, \& C. Netscher. 1993. Penyebaran dan Patogenisitas Nematoda Puru Akar Padi (Meloidogyne graminicola) di D.I. Yogyakarta. BPPS-UGM 6 (4B): 439-452.

Esbenshade, P.R. \& A.C.Triantaphyllou. 1990. Isozyme Phenotypes for the Identification of Meloidogyne species. Journal of Nematology. 22: 10-15. 
Febriyani, D. 2003. Nematoda Puru Akar (Meloidogyne spp.) pada Tanaman Padi Sawah di Kelurahan Situ Gede, Bubulak, Kecamatan Bogor Barat dan Desa Caringin, Kecamatan Darmaga, Bogor. Skripsi. Institut Pertanian Bogor. Bogor. 46 hlm.

Golden, A.M. \& W. Birchfield. 1965. Meloidogyne graminicola (Heteroderidae), a New Species of Root Knot Nematode from Grasses. Proceeding Helminthological Society of Washington 32: 228-231.

Goodey, T. 1973. Two Methods for Staining Nematodes in Plant Tissue. Journal of Helminthology 15: 137-144.

Hooper, D.J., J. Hallmann, \& S.A.Subbotin. 2005. Methods for Extraction, Processing and Detection of Plant and Soil Nematodes, p. 53-86. In M. Luc, R. A. Sikora, \& J. Bridge (ed). Plant Parasitic Nematodes in Subtropical and Tropical Agriculture. Ed ke-2. CABI., London, UK.

Hunt, D.J. \& Z.A. Handoo. 2009. Taxonomy, Identification, and Principal Species, p. 55-88. In R.N. Perry, M. Moens, \& J.L. Starr (eds.), Root Knot Nematode. CABI, Cambridge.

Jaiswal, I.R.K., K.P. Singh, \& R.K. Mishra. 2011. A Technique for the Detection of Soil Infestation with Rice Root-knot Nematode, Meloidogyne graminicola at Farmer's Field. Academic Journal Plant Science 4: 110-113.

Mai, W.F. \& H.H. Lyon. 1996. Pictorial Key to Genera of Plant Parasitic Nematodes. $5^{\text {th }}$ Edition. Cornel University, New York. 277 p.

Mirsam, H., Supramana, \& G. Suastika. 2015. Deteksi dan Identifikasi Spesies Meloidogyne pada Tanaman Wortel dari Dataran Tinggi Malino, Gowa, Sulawesi Selatan. Jurnal Fitopatologi Indonesia 11: 1-8.
Mirsam, H., Supramana, \& G. Suastika. 2015. Identifikasi Nematoda Parasit pada Tanaman Wortel di Dataran Tinggi Malino, Sulawesi Selatan Berdasarkan pada Ciri Morfologi dan Morfometrik. Jurnal Fitopatologi Indonesia 11: 85-90.

Mulyadi. 1994. Nematoda Puru Akar Padi (Meloidogyne graminicola) di DI Yogyakarta dan Usaha Pengendaliannya. Lembaga Penelitian UGM, Yogyakarta. $23 \mathrm{hlm}$.

Mulyadi \& B. Triman. 1995. Kajian Tanaman Inang Nematoda Puru Akar Padi (Meloidogyne graminicola). Jurnal Perlindungan Tanaman Indonesia 7: 79-85.

Nurjayadi, M.Y., A. Munif, \& G. Suastika. 2015. Identifikasi Nematoda Puru Akar, Meloidogyne graminicola, pada Tanaman Padi di Jawa Barat. Jurnal Fitopatologi Indonesia 11: 113-120.

Padgham, J.L., J.M. Duxbury, A.M. Mazid, G.S. Abawi, \& M. Hossain. 2004. Yield Loss Caused by Meloidogyne graminicola on Lowland Rainfed Rice in Bangladesh. Journal of Nematology 36: 42-48.

Pokharel, R.R., G.S. Abawi, N. Zhang, J.M. Duxbury, \& C.D. Smart. 2007. Characterization of Isolates of Meloidogyne from Rice-Wheat Production Fields in Nepal. Journal of Nematology 39: 221-230.

Powers, T.O., T.C. Todd, A.M. Burnell, P.C.B. Murray, C.C. Fleming, A.L. Szalanki, B.A. Adams, \& T.S. Harris. 1997. The rDNA Internal Transcribed Spacer Region as a Taxonomic Marker for Nematodes. Journal of Nematology 29: 441-450.

Shurtleff, M.C. \& C.W. Averre. 2005. Diagnosing Plant Disease Caused by Nematodes. APS Press, St. Paul, Minnesota, US. 187 p.

Zouhar, M., P. Ryšánek, \& M. Kočová. 2000. Detection and Differentiation of the Potato Cyst Nematodes Globodera pallida and Globodera rostochiensis by PCR. Plant Protection Science 36: $81-84$. 